\title{
The Effect of Polypropylene Tree Shelters on Growth and Survival of Pedunculate Oak Seedlings (Quercus robur L.)
}

\author{
Boris Liovićn ${ }^{1 *}$, Željko Tomašić ${ }^{2}$, Tomislav Dubravac ${ }^{3}$, Robert Licht ${ }^{4}$, Matej Turk ${ }^{5}$
}

(1) Croatian Forest Research Institute, Division for Forest Protection and Game Management, Cvjetno naselje 41, HR-10450 Jastrebarsko, Croatia; (2) Croatian Forests Ltd., Kneza Branimira 1, HR-10 000 Zagreb, Croatia; (3) Croatian Forest Research Institute, Division for Silviculture, Cvjetno naselje 41, HR-10450 Jastrebarsko, Croatia; (4) Croatian Forest Research Institute, Research Centre for Lowland Forests, Trg Josipa Runjanina 10, HR-32100 Vinkovci, Croatia; (5) "ŠUME - obrt za savjetovanje u šumarstvu, usluge i trgovinu", Supilova 7, HR-10000 Zagreb, Croatia

* Correspondence: e-mail: borisl@sumins.hr
Citation: LIOVIĆ B, TOMAŠIĆ Ž, DUBRAVAC T, LICHT R, TURK M 2019 The Effect of Polypropylene Tree Shelters on Growth and Survival of Pedunculate Oak Seedlings (Quercus robur L.). South-east Eur for 10 (1): 89-96. DOI: https://doi.org/10.15177/ seefor.19-07

Received: 3 Dec 2018; Revised: 1 Apr 2019; 15 Apr 2019; Accepted: 18 Apr 2019; Published online: 16 May 2019

\begin{abstract}
Background and Purpose: The declining and dieback of lowland oak forests as the result of global climate change, as well as the attack of various pathogenic organisms, industrial pollution, and other negative effects reduce acorn yield and will continue to do so in the future. As a result of this fact, the areas on which artificial regeneration will be applied by planting seedlings will have to be increased. The artificial regeneration process is more expensive than the natural one, so protection measures need to be applied to minimize the loss of young seedlings.

Materials and Methods: Experimental plots were set up in the forest area of Spačva Basin. A completely randomized block design experiment in four repetitions was used, in which four variants of planting and protection of oak seedlings were examined. We tested polypropylene tree shelters and hydrophilic superabsorbent based on maize starch. Heights of the plants were measured by measuring tape, and survival was registered by numbering of dead and living plants. For statistical purposes, we have used analysis of variance (repeated measure ANOVA), which allows us to prove statistically significant difference between morphological traits of studied variants.

Results: Two years after planting, the lowest level of survival was found in unprotected seedlings (79.5\%), while tree shelters provided the best conditions for seedlings survival $(88.75 \%)$. In the case with the hydrophilic granules Zeba the result is slightly worse. When analyzing average height in a particular case, significantly higher plants are recorded in cases where the polypropylene tree shelters are used. The average height, with tree shelters $(128.27 \mathrm{~cm})$, is more than three times higher than the unprotected seedlings $(37.97 \mathrm{~cm})$. The addition of hydrophilic granules did not show a statistically significant difference. In cases where the seedlings were not under the tree shelter protection, the effect of hydrophilic granules was also not statistically significant.

Conclusions: Sheltering accelerated the height growth of the planted oaks substantially and also provided best conditions for seedlings survival. During the research period the usage of Zeba did not justify the purpose for which it was applied. Although the first results are promising in order to gain a complete insight into the potential of tree shelters it is necessary to record the changes and maintain the experiment for a further 2-3 years with quantification of other harmful factors that may appear (drought, game etc.) after which a more reliable judgment regarding their usefulness could be provided.
\end{abstract}

Keywords: Spačva Basin, artificial regeneration, Zeba granules, polypropylene tree shelters, Corythucha arcuata, Microsphaera alphitoides, pedunculate oak

\section{INTRODUCTION}

The decline of pedunculate oak (Quercus robur L.) in the last few decades has been intense in the whole territory of its areal [1-3], and Croatia is no exception [4, 5]. From the total felled tree volume of pedunculate oak trees from forests of Spačva in the period from 1996 to 2006 almost $58 \%$ referred to dead and damaged trees [6]. Changes in the water regime (decrease in groundwater level or increase in humidity, or the so-called "swamping"), along with the 
influence of droughts [6], water and air pollution, and tree defoliation due to insects or fungi, are the most important factors that cause dying of oak trees in Croatia [7, 8]. Most recently, new invasive species the oak lace bug (Corythucha arcuata), which has potential negative impact, has been spotted in pedunculate oak stands in Croatia [9], but changes in the vegetation cover have been recorded as well, in the form of movement to drier plant communities [10, 11]. Along with all the above mentioned facts, as well as the trend of average, maximum and minimum air temperature rise throughout Croatia [12] and models predicting decrease in quantities of rainfall in the wettest but also in the driest months [13], management of oak stands will require adaptation to the actual occurrence of climate change, both in Croatia and south Europe [14]. Reconstruction of these stands in the future will be a real challenge and an increase in the intensity of the forest works can be expected, as well as changes in the ways of management so far, in terms of adaptive forest management. The main characteristic of adaptive forest management is the flexibility and adaptation of all activities to the specific biological, ecological and structural features of forest ecosystems and the changes that occur in [15].

Global climate change and the attack of various pathogenic organisms lead to the decline of forests or dieback of trees in forest. Lowland forests of pedunculate oak and other lowland tree species are most intensively affected by these occurrences $[16,17]$. This process manifests itself as the defoliation of tree crowns $[18,19]$. With increased intensity of crown defoliation, the yield of acorn decreases as well [20]. Forest areas with increased intensity of defoliation or the share of areas with significantly defoliated crowns of oak trees are growing [18], and it is expected that the area on which artificial regeneration with seedlings will have to be applied will increase as well. The artificial regeneration process is more expensive than the natural one, so the loss of seedlings is not economically acceptable, because in that case the whole work would have to be repeated several times.

Competitiveness of weeds and game is the most harmful factor that reduces plant growth and survival. Dense weeds quickly overgrow seedlings, overshadow them, and reduce the intensity of photosynthesis, which affects plant vitality and height gain [21]. In addition, weeds are very competitive for water and nutrition to planted young seedlings. In winter, the overhanging parts of weeds mechanically press and bend the seedlings. The game cut off the tops of seedlings and thus reduce their competitiveness compared to the weeds surrounding them [22].

Polypropylene tree shelters, which in 1979 were introduced by the English forester Graham Tuley, can significantly reduce the negative impact of weeds and game. As reported by Jeffrey and Stephens [23] due to wild game browsing the leaves of unprotected black walnut, seedlings were higher at the start of the experiment than three years later, while the protected seedlings grew from $36.1 \mathrm{~cm}$ to $89.0 \mathrm{~cm}$. Liović [24] states that $20 \%$ of unprotected plants had a cut-off top of the seedlings.

The use of the polypropylene tree shelters does not exclude the use of herbicides (used during preparation site for stand regeneration and for several sprayings after planting), but fewer quantities are spent because the whole surface for regeneration is not needed to be sprayed. After the planting, once a year herbicide spray needs to be applied to the $1 \mathrm{~m}$ diameter around each tree shelter, which is economically and ecologically more favorable [25].

The use of the polypropylene tree shelters also reduces to some extent the onset of plant disease (powdery mildew) due to the specific climate within it [26]. Similarly, Liović [24] in his research states that $15 \%$ of unprotected control plants were browsed by oak defoliators while seedlings within the shelters were not damaged. The basic advantage of polypropylene tree shelters is the accelerated height increase of seedlings and their survival, as reported by many authors [24, 27-29]. The rapid height increase shortens the time of the plant growing in the shadow of weeds and has a significantly higher probability of survival.

Pedunculate oak seedlings and offspring were particularly sensitive to the conditions of weed competition because of their great demands for light. Therefore, in the first few years after planting, it is necessary to tend young oak plants, i.e. to release them from weeds. The procedure is not easy because of the fact that on eutrophic and wet soils the weeds grow rapidly and turn into lush (Figure 1). Therefore, during the year it is needed to tend them at least twice. Mechanical treatment with a large number of people is expensive and, because of young people leaving to work abroad, there is a problem of the lack of workers today. The use of herbicides on large surfaces is neither ecologically nor economically justified. Due to the problems mentioned above, the aim of this study is the implementation of forest regeneration methods into forestry practice which are not labor intensive and which include less use of pesticides.

\section{MATERIALS AND METHODS}

Experimental plots were set up (November 2014) in the area of Forest Administration (FA) Vinkovci, Forest Office (FO) Županja, Management Unit (MU) Kragujna, Rašćica, Compartment (Comp.) 35a. This area belongs to the forest

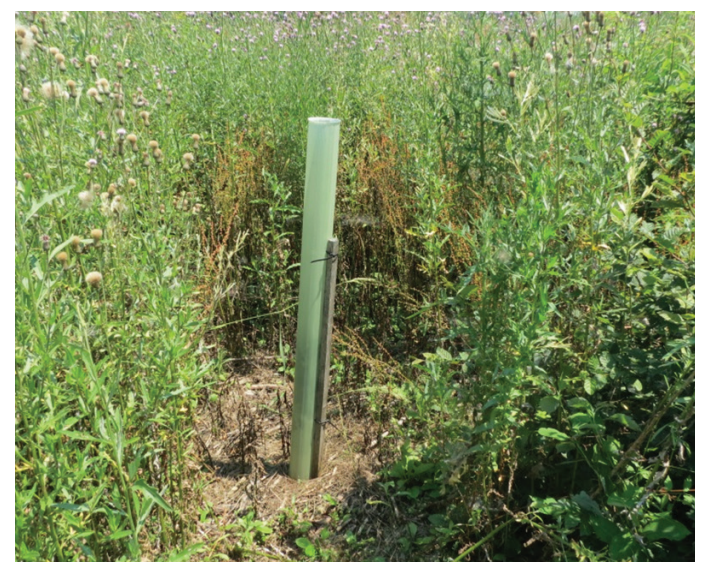

FIGURE 1. Eutrophic and humid soil supports the rich growth of weeds. 
area of Spačva Basin, one of the largest complexes of lowland pedunculate oak forests in Europe, where the management class of oak forests occupy $96 \%$ of them and spread over 40.000 ha (1/5 of all pedunculate oak forest stands in Croatia). Because of its specific hydrological characteristics, almost the whole area is situated on alluvial flat terrain with moderate micro-elevations. The main types of soil are accompanied by a topological gradient: pseudogley and pseudogley-gley dominate on river terraces, while different types of gley soil are found on micro-elevations and microdepressions [30].

Research plots have been placed in relative forest soil area that had been for a long time overgrowing with scarce bushy vegetation, sometimes used as wild game feeding grounds. The scope of the experimental field encompasses the area of light-strips along the forest road that has been used for a long time for this purpose (Figure 2). There is also a trench along the forest road for the purpose of drainage (as the element of the road) with additional enlargement for its maintenance. Nearby old oak stands on micro-elevation belong to the forest community of common hornbeam and pedunculate oak forests (Carpino betuli - Quercetum roboris, Rauš 1969) located on the edge of the micro-depression area where the experimental plots are situated.

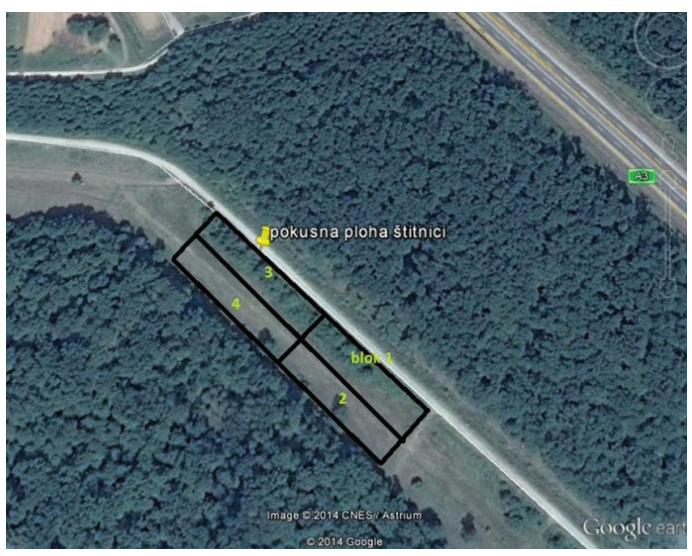

FIGURE 2. Trial location (FA Vinkovci, FO Županja, MU Kragujna, Rašćica, Comp. 35a).
The climate in this part of Croatia is continental. The average annual temperature is $11.4^{\circ} \mathrm{C}$, the hottest month is August, with a moderate temperature of $21.8^{\circ} \mathrm{C}$, while the coldest month is January, with an average temperature of -0.5 o $\mathrm{C}$. The average rainfall is $686 \mathrm{~mm}$, with a maximum in June [31].

The object of the study are pedunculate oak seedlings used for the regeneration of oak forests in this area through various methods. In the study a completely randomized block design experiment in four repetitions was used, in which four variants of planting and protection of oak seedlings were examined (Figure 3).

Each repetition consisted of four variants: seedlings protected with polypropylene shelters with addition of hydrophilic granules Zeba (SŠHG), seedlings protected with polypropylene shelter (SŠ), seedlings without protection and Zeba (S), and unprotected seedlings with addition of Zeba (SHG).

Zeba (United Phosphorus, Inc.) is a superabsorbent based on maize starch whose high water absorption capacity (500 times their own weight) is used to improve the supply of water to seedlings during the dry season [32, 33]. Additionally, it is completely biodegradable. Numbers of seedlings are shown in Table 1.

Polypropylene shelters are cream-colored, green or brown, made of double layer polypropylene, resistant to UV rays. The upper edge of the tree shelter was bent outwards to avoid damage to the plants after it had overgrown. Due to the more economical and easier transport and storage, the shelters selected for this experiment are packed in 4 pieces, one in the other, so their diameters are between 8.3 and $10.8 \mathrm{~cm}$. They are manufactured to be from $0.2 \mathrm{~m}$ high for

TABLE 1. Different cases and the number of seedlings of pedunculate oak.

\begin{tabular}{cc}
\hline Case & Number of seedlings (pieces) \\
\hline SŠHG & 280 \\
SŠ & 280 \\
S & 800 \\
SHG & 800 \\
Total & 2160 \\
\hline
\end{tabular}

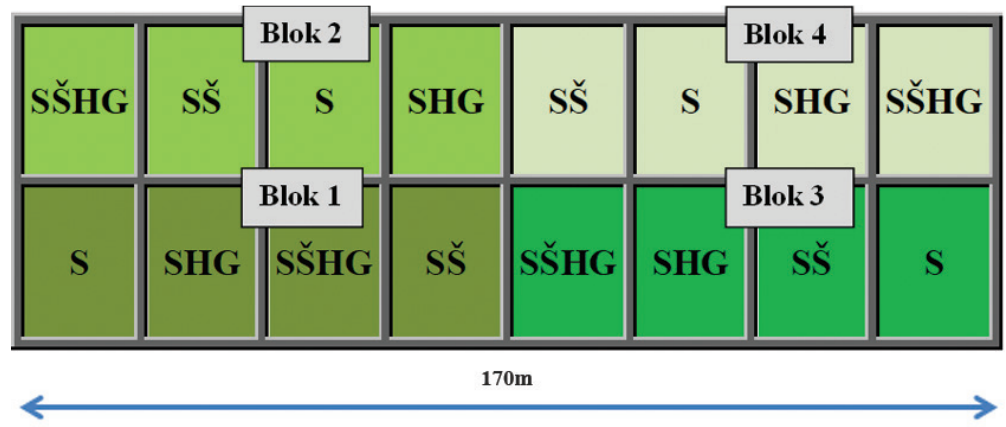

FIGURE 3. Completely randomized block design experiment in four repetitions. 
the protection from voles and up to $1.8 \mathrm{~m}$ for the protection from wild game (common and roe deer). We used $1.2 \mathrm{~m}$ height shelters. The shelter is secured using a stake and is fastened with two plastic straps.

In order to reduce the negative impact of weeds, during the month of May around every shelter in the circle of 1 meter diameter all vegetation was sprayed with herbicide based on the glyphosate active substance (Figure 4). However, the weeds continued to grow lushly, so in 2016 herbicide was applied in diameter of 1 meter around each shelter again.

At the end of the vegetation period, for each seedling the total height were measured by measuring tape and the survival were established by numbering of dead/living plants.

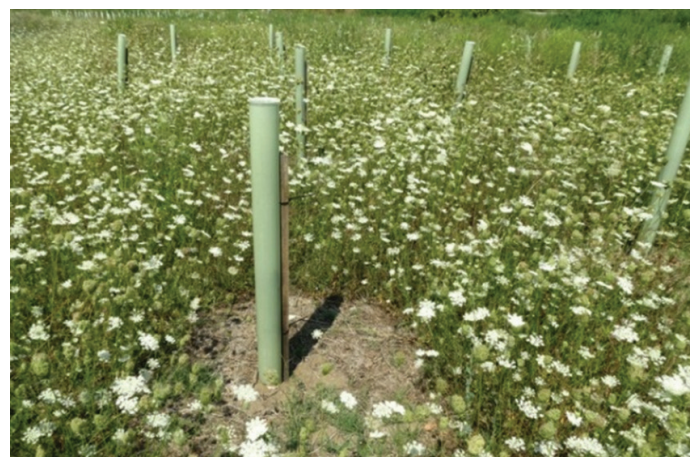

FIGURE 4. Herbicide treatment around tree shelters.
Any biotic factors that occurred during the study period and that could negatively affect the growth and development of seedlings were just visually recorded without analyzing the impact on the growth and development.

With the aim of answering set research question, we have used analysis of variance (repeated measure ANOVA), which allows us to prove statistically significant difference between morphological traits of studied variants. In cases when statistically significant difference between variants was confirmed, it was necessary to determine which variants differed. Thus, differences gathered by repeated measures ANOVA were tested with „post hoc“ LSD test. Type I error (5\%) was regarded as statistically significant. Furthermore, descriptive statistics was compiled for acquired data. Data analysis was conducted using Statistica software (StatSoft Inc. 2007) [34]. The condition of variance homogeneity is satisfied.

\section{RESULTS AND DISCUSSION}

\section{Survival}

The results are shown in tabular form (Table 2) and graphically (Figure 5). Planting which includes the protection and support by polypropylene tree shelters provided the best conditions for seedlings survival, so in that case $88.75 \%$ seedlings survived. In the case where Zeba were used the results are slightly inferior (87\%) and it can be said that they do not justify its application. The lowest survival rate was in the case of unprotected seedlings (79.5\%). Seedlings without protective shelters, but with the addition
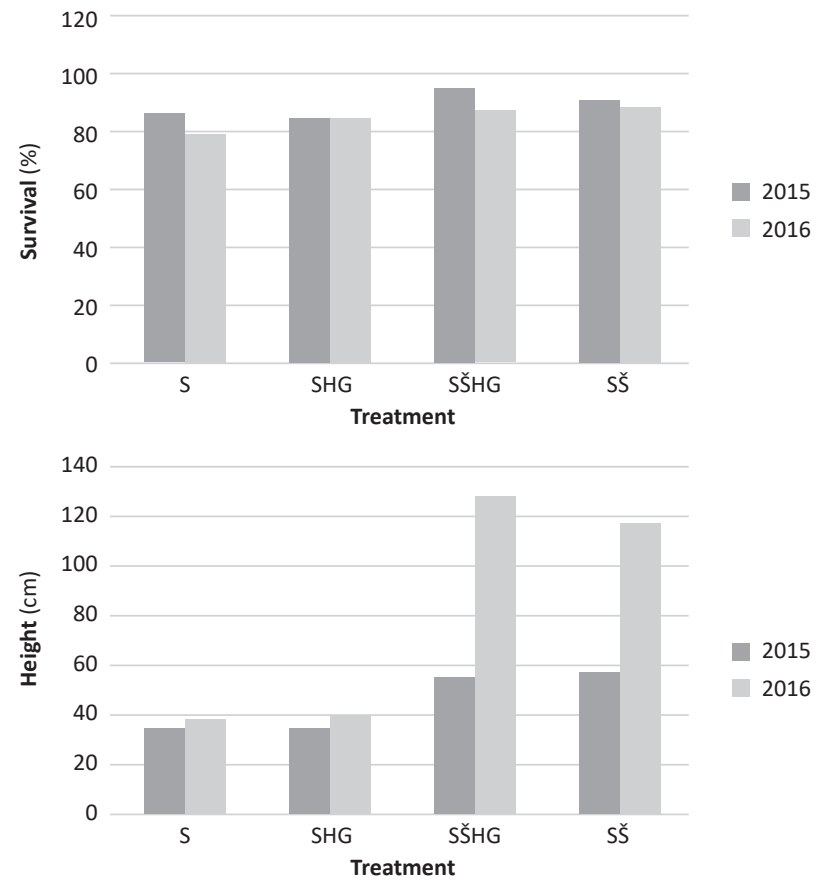

FIGURE 5. Survival and height of seedlings during research period. 
of hydrophilic granules have about $5 \%$ better chances of survival. These results are in agreement with the results of Liović [35], in which the mortality rate of oak seedlings protected by shelters was $6 \%$ and unprotected seedlings $24 \%$, but we must emphasize that Liović [35] did not study effects of Zeba. In Valkonen [36] sheltering improved the survival of planted seedlings of pedunculate oak a little, but the difference was not significant.

TABLE 2. Survival and height of seedlings at the end of 2015 and 2016 vegetation.

\begin{tabular}{|c|c|c|}
\hline Case & $\begin{array}{c}\text { Survival } \\
(\%)\end{array}$ & $\begin{array}{l}\text { Height (ME } \pm \text { SD) } \\
(\mathrm{cm})\end{array}$ \\
\hline \multicolumn{3}{|c|}{2015} \\
\hline SŠHG & 95.57 & $54.94 \pm 17.26$ \\
\hline SŠ & 91.97 & $56.64 \pm 17.37$ \\
\hline S & 86.46 & $34.36 \pm 9.70$ \\
\hline SHG & 85.54 & $34.71 \pm 9.41$ \\
\hline \multicolumn{3}{|c|}{2016} \\
\hline SŠHG & 87.00 & $128.72 \pm 33.42$ \\
\hline SŠ & 88.75 & $117.27 \pm 41.27$ \\
\hline$S$ & 79.50 & $39.04 \pm 12.62$ \\
\hline SHG & 84.75 & $37.97 \pm 12.01$ \\
\hline
\end{tabular}

ME - mean; SD - standard deviation

\section{Height}

ANOVA showed statistically significant difference between variants height during research period (ANOVA: $F=18.156, p<0.001)$. These points to the fact that variants do not act in a similar way during the investigated years. When analyzing the mean height in a particular case (Figure 5 , Table 2), it was found that the results were higher in cases where polypropylene tree shelters are used. The average height with tree shelter protection is more than three times bigger than of the unprotected seedlings. The results are comparable to the measured plant heights after 2 years of research in the Lantagne [29]. In this experiment, control seedlings were three times lower than those protected by the shelters since the weed competition was significantly stronger. Namely the weeds around the shield were treated with a systemic herbicide that destroys overground parts of the weed but also the root of the weeds. On the other hand weeds on control unprotected seedlings were mechanically removed and shortly thereafter re-growth and compete for nutrition, water and light. Liović [35] presents similar results: 6 vegetation periods after planting, the average height of oak planters protected by shelters was over $200 \mathrm{~cm}$ and the height of unprotected seedlings $50 \mathrm{~cm}$, while some seedlings reached a height of up to $4 \mathrm{~m}$. In Valkonen [36] sheltering had accelerated the height growth of the planted oaks substantially. Other studies under different conditions had similar results regarding height growth and survival [29, $37,38]$. Such increase in height allowed a rapid outgrow of the weed competition zone (Figure 6) and brought all the benefits that have resulted in such heights. We believe that such a large difference in height between unprotected and sheltered seedlings was due to the effective application of systemic herbicides that reduced the competition of weeds in protected plants for a long time.

The tendency of trees to grow taller with increasing water availability is common knowledge. There are also numerous studies about tree height and water availability [39-41]. Based on that studies and high water absorption capacity of Zeba we hypothesized that variants with added Zeba would be taller than variants without it. But our results showed that addition of hydrophilic granules affected the average height increase only by about $10 \mathrm{~cm}$. In cases where the seedlings are not sheltered, the effect of hydrophilic granules is very small, around $2 \mathrm{~cm}$.

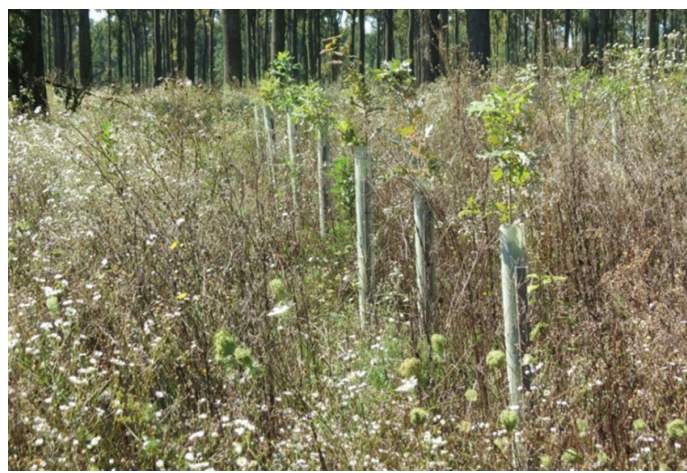

FIGURE 6. Faster growth makes it possible to quickly leave the competition zone of weeds.

SŠHG significantly differs from SŠ $(p<0.001), S(p<0.001)$ and SHG $(p<0.001)$. SŠ significantly differs from $S(p<0.001)$ and SHG $(p<0.001)$. There is no significant difference between $S$ and SHG $(p=0.315)$.

\section{Biotic Factors}

During the year 2015, attack of the oak lace bug (Corythucha arcuata Say) and the oak slug sawfly (Caliroa annulipes Klug.) have been recorded during the trial (Figure 7). Pesticides were not used.

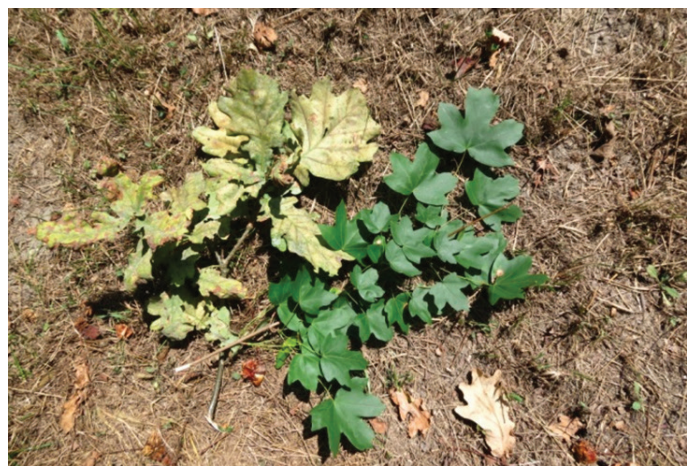

FIGURE 7. Attack of the oak lace bug (green leafs of field maple for comparison). 
During the year 2016, an attack of powdery oak mildew - (Microsphaeraa alphitoides Griff. et Maubl) that covered almost all plants that overgrow the height of the shelter was recorded (Figure 8). Fungicide protection measures were not implemented.

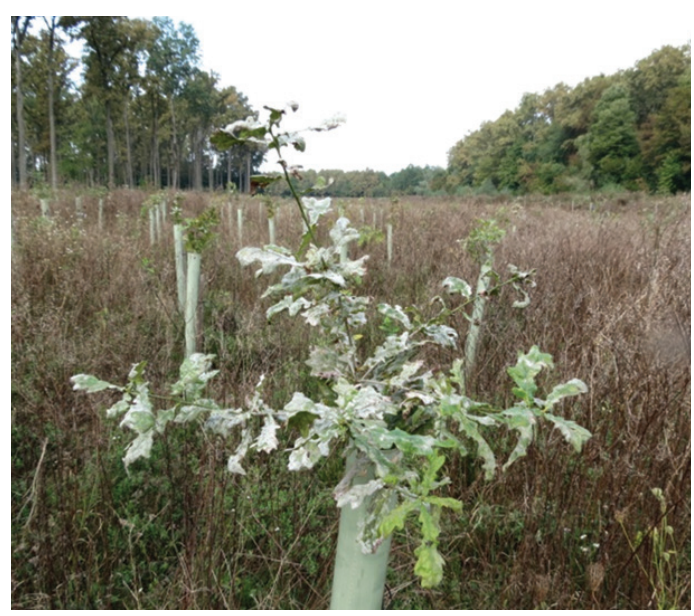

FIGURE 8. Attack of powdery oak mildew.

Inside the shelter powdery oak mildew is visually weaker or is not present (Figure 9). Stakes (with a bigger white mass on outer wood) decayed in two years, broke and the shelters fell, so the plants bent down as well (Figure 10). Fortunately, the plants did not break, so it was enough to replace the stake and reset the shelter.

\section{CONCLUSIONS}

During the two-year period of research, in case where the polypropylene shelters were used, seedlings are found to be significantly higher than in non-sheltered cases. The average height of the shelter-protected seedlings (128.27 $\mathrm{cm}$ ) is more than three times taller than of the unprotected seedlings $(37.97 \mathrm{~cm})$. Likewise, survival of unprotected seedlings that were most exposed to harmful factors was $79.5 \%$, while planting within the shelter provided the best conditions for seedlings survival (88.75\%). We believe that such a large difference in height between unprotected and sheltered seedlings was due to the effective application of systemic herbicides that reduced the competition of weeds in protected plants for a long time. During the observed study period, the use of the Zeba superabsorbent which is well-known for its water absorption capacities, did not significantly affect the growth and development of seedlings. In order to gain a complete insight into the potential of protection in terms of protecting planters from unfavorable factors, it is necessary to record the changes and maintain

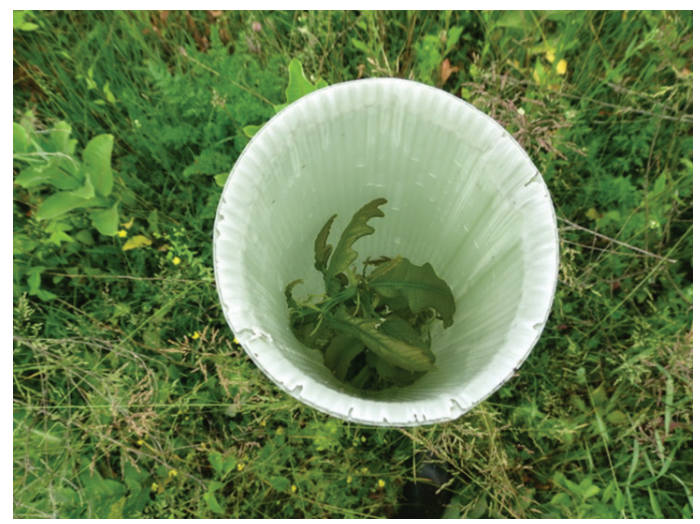

FIGURE 9. Inside the shelter powdery oak mildew did not generally developed.

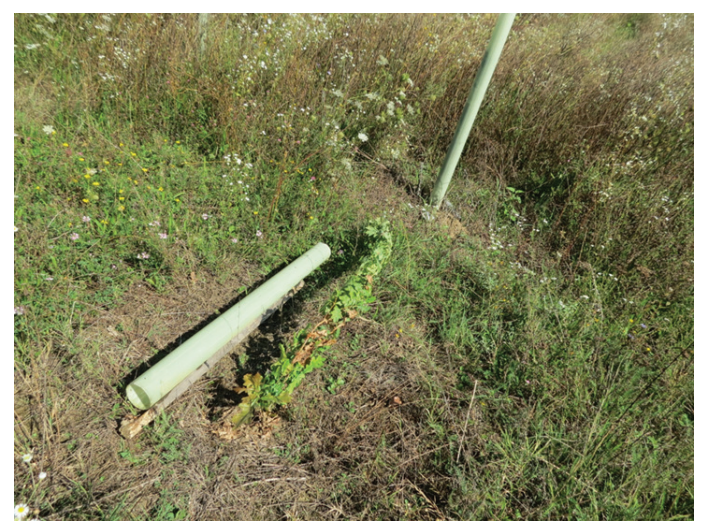

FIGURE 10. Prostrated plan.

the experiment for a further 2-3 years with quantification other harmful factors that may appear (drought, game etc.) after which a more accurate judgment on their usable value could be given. Also, one must be aware that using pedunculate oak for artificial regeneration without shelters requires repeated weed control measures for a longer time period- a costly burden that forest owners may tend to underestimate at the planning stage.

\section{Acknowledgments}

Studies were carried out as part of the three-year scientific project "Ecological climate change and the problem of regeneration of pedunculate oak forests in Spačvanski bazen" (2014-2016) thanksgiving the project that was ordered and financed by Croatian Forests, Ltd. 


\section{REFERENCES}

1. THOMAS FM, BLANK R, HARTMANN G 2002 Abiotic and biotic factors and their interactions as causes of oak decline in Central Europe. For Pathol 32 (4-5): 277-307. DOI: https:// doi.org/10.1046/j.1439-0329.2002.00291.x

2. SONESSON K, DROBSHYEV I 2010 Recent advances on oak decline in southern Sweden. Ecol Bull 53: 197-207

3. STOJANOVIĆ DB, LEVANIČ T, MATOVIĆ B, ORLOVIĆ S 2015 Growth decrease and mortality of oak floodplain forests as a response to change of water regime and climate. Eur J For Res 134 (3): 555-567. DOI: https://doi.org/10.1007/s10342015-0871-5

4. DUBRAVAC T, DEKANIĆ S 2009 Structure and dynamics of the harvest of dead and declining trees of pedunculate oak in the stands of Spačva forest from 1996 to 2006. Sumar List 133 (7-8): 391-405 (in Croatian with English summary)

5. DUBRAVAC T, DEKANIĆ S, ROTH V 2011 Damage dynamics and structure of the pedunculate oak tree crowns in stands in microelevations and microdepressions - results from the monitoring on permanent experimental plots. Sumar List 135 (13): 74-89 (in Croatian with English summary)

6. NEMEŠ T, DEKANIĆ S 2013 Groundwater regime of Biđ-Bosut forest area. Rad Šumar Ins Jastrebar 45 (2): 145-159

7. PRPIĆ B 1996 Degradation of Pedunculate oak forests. In: Klepac D (ed) Pedunculate oak in Croatia. HAZU and Hrvatske šume, Zagreb, Croatia, pp 273-298

8. VUKELIĆ J, TIKVIĆ I, SELETKOVIĆ Z, BARIČEVIĆ D 1997 Dieback of Pedunculate oak from the ecological-vegetative aspect. In: Spiecker H, Rogers R, Somogyi Z (eds) Proceedings advances in research in intermediate oak stands. International union of forestry research organizations, Freiburg, Germany, pp 213-222

9. HRAŠOVEC B, POSARIĆ D, LUKIĆ I, PERNEK M 2013 First record of oak lace bug (Corythucha arctuata) in Croatia. Sumar List 137(9-10): 499-503 (in Croatian with English summary)

10. RAUŠ $Đ 1990$ Succession of forest vegetation in the Spačva basin from 1970 to 1989. Sumar list 116 (9-10): 341-354 (in Croatian with English summary)

11. CESTARIĆ D, ŠKVORC Ž, FRANJIĆ J, SEVER K, KRSTONOŠIĆ D 2017 Forest plant community changes in the Spačva lowland area (E Croatia). Plant Biosyst 151 (4): 584-597. DOI: https:// doi.org/10.1080/11263504.2016.1179699

12. DHMZ 2013 Sixth National Communication of the Republic of Croatia under the United Nation Framework Convention on the Climate Change (UNFCCC). Selected sections in chapters: 7. - Climate change impacts and adaptation measures 8. - Research, systematic observation and monitoring: $126 \mathrm{p}$

13. UGARKOVIĆ D, TIKVIĆ I, MIKAC S, STANKIĆ I, BALTA D 2016 The influence of changing climate extremes on the ecological niche of pedunculate oak in Croatia. South-east Eur for 7 (2): 143-148. DOI: https://doi.org/10.15177/seefor.16-17

14. BARSOUM N, EATON EL, LEVANIČ T, PARGADE J, BONNART $X$, MORISON JIL 2014 Climatic drivers of oak growth over the past one hundred years in mixed and monoculture stands in southern England and northern France. Eur J For Res 134 (1): 33-51. DOI: https://doi.org/10.1007/s10342-014-0831-5

15. BOLTE A, AMMER C, LÖF M, NABUURS GJ, SCHALL P, SPATHELF P 2010 Adaptive Forest Management: A Prerequisite for Sustainable Forestry in the Face of Climate Change. In: Spathelf P (eds) Sustainable Forest Management in a Changing World - a European Perspective. Springer Science + Business Media B.V., pp 115-139. DOI: https://doi. org/10.1007/978-90-481-3301-7 8
16. PERNEK $M$, PILAŠ I, VRBEK $B$, BENKO $M$, HRAŠOVEC $B$, MILKOVIĆ J 2008 Forecasting the impact of the Gypsy moth on lowland hardwood forests by analyzing the cyclical pattern of population and climate data series. Forest Ecol Manag 255 (5-6): 1740-1748. DOI: https://doi. org/10.1016/j.foreco.2007.11.031

17. ČATER M 2015 A 20-year overview of Quercus robur L. mortality and crown conditions in Slovenia. Forests 6 (3) 581-593. DOI: https://doi.org/10.3390/f6030581

18. РОTOČIĆ N, SELETKOVIĆ I 2011 Defoliation of forest trees in Croatia in the period 2006 - 2009. Sumar List 135 (13) 149158 (in Croatian with English summary)

19. DROBYSHEV I, ANDERSON S, SONESSON K 2007 Crown condition dynamics of oak in southern Sweden 1988-1999. Environ Monit Assess 134 (1-3): 199-210. DOI: https://doi. org/10.1007/s10661-007-9610-9

20. GRADEČKI-POŠTENJAK M, NOVAK AGBABA S, LICHT R, POSARIĆ D 2011 Dynamics of acorn production and quality of english oak acorn (Quercus robur L.) in disrupted ecological conditions. Sumar List 135 (13): 169-180. DOI: (in Croatian with English summary)

21. MYERS BJ 1988 Water stress integral - a link between shortterm stress and long-term growth. Tree Physiol 4 (4) 315-323

22. WATT MS, WHITEHEAD D, MASON EG, RICHARDSON B, KIMBERLEY MO 2003 The influence of weed competition for light and water on growth and dry matter partitioning of young Pinus radiata, at a dryland site. Forest Ecol Manag 183 (1-3): 363-376. DOI: https://doi.org/10.1016/S03781127(03)00139-7

23. JEFFREY SW, STEPHENS GR 1995 Protection of Tree Seedlings from Deer Browsing. In: Gottschalk KW, Fosbroke SLC (eds) Proceedings of the 10th Central hardwood forest conference, Morgentown, WV, USA, 5-8 March 1995. Division of Forestry, West Virginia University; Northeastern Forest Experiment Station, USDA Forest Service, USA, pp 507-514

24. LIOVIĆ B 1993 Zaštita sadnica šumskog drveća polipropilenskim štitnicima. Rad Šumar Ins Jastrebar 28 (12): $255-262$

25. LIOVIĆ B, TOMAŠIĆ Ž, STANKIĆ | 2013 Ecological and Economic Advantages of Using Polypropylene Tree Shelters in Lowland Oak Forests. South-east Eur for 4 (2): 115-125. DOI: https://doi.org/10.15177/seefor.13-12

26. LIOVIĆ B, OCVIREK M 1997 Plastic treeshelters in the conception of integral forest seedling protection. Radovi Šumar inst Jastrebar 32 (1): 31-42 (in Croatian with English summary)

27. BAINBRIDGE DA 1991 Successful tree establishment on difficult dry sites. In: Proceedings of Third International Windbreaks and Agroforestry Symposium, Ridgetown, ON, Canada. Ridgetown College, Canada, pp 78-81

28. POTTER MJ 1988 Treeshelters improve survival and increases early growth rates. J Forest 86 (8): 39-41

29. LANTAGNE DO 1995 Effects of Tree Shelters on Planted Red Oaks After Six Growing Seasons. In: Gottschalk KW, Fosbroke SLC (eds) Proceedings of the 10th Central hardwood forest conference, Morgentown, WV, USA, 5-8 March 1995. Division of Forestry, West Virginia University; Northeastern Forest Experiment Station, USDA Forest Service, USA, pp 515-522

30. VRBEK B, PILAŠ I, PERNAR N 2011 Observed climate change in Croatia and its impact on the hydrology of lowlands. In: Bredemeier M, Cohen S, Godbold DL, Lode E, Pichler V, Schleppi P (eds) Forest management and the water cycle, An ecosystem-based approach. Ecological Studies (Analysis and Synthesis), vol 212, pp 141-162, Springer, Dordrecht. DOI: https://doi.org/10.1007/978-90-481-9834-4 8 
31. Data from Meteorological and Hydrological Service at Vinkovci measuring station for the period of 1961-2010

32. VIZITIU O, SIMOTA C, CALCIU I, LOANA P 2013 Increasing the plant water availability as an effect of superabsorbents application. Proceedings of Conference: Conference: Cea de a XX-a Conferinţă Naţională de Ştiinţa Solului, cu participare internaţională, Craiova, Romania, Volume: Agricultura, Montanologie, Cadastru vol. XLII-2012/1

33. NGOBENI ND, BUTHELEZI NM, MATARUKA D 2007 Growth and yield response of cotton cultivars to "Zeba” superabsorbent polymer and $\mathrm{N}$-application under irrigation. Proceedings of the African Crop Science Conference 8, pp 213-217

34. STATSOFT, INC.2006 STATISTICA (data analysis software system), version 7

35. LIOVIĆ B 2001 Results of application of polypropylene shelters for the protection of common oak seedlings - sixyear experiment. In: Matić S, Krpan A P B, Gračan J (eds) Science in Sustainable Management of Croatian Forests. Faculty of Forestry Zagreb; Croatian Forest Research Institute, Zagreb, pp 309-317
36. VALKONEN S 2008 Survival and growth of planted and seeded oak (Quercus robur L.) seedlings with and without shelters on field afforestation sites in Finland. Forest Ecol Manag 255 (3-4): 1085-1094. DOI: https://doi. org/10.1016/i.foreco.2007.10.038

37. POTTER M 1991 Treeshelters. Forestry Commission Handbook 7: $48 p$

38. WALTERS R 1993 Protecting red oak seedlings with tree shelters in north- western Pennsylvania. USDA Forest Service Northeastern Research Station General Research Papers 679: $5 p$

39. RYAN MG, YODER BJ 1997 Hydraulic limits to tree height and tree growth. Biosci 47 (4):235-242

40. KOCH GW, SILLETT SC, JENNINGS GM, DAVIS SD 2004 The limits to tree height. Nature 428 (6985): 851-854. DOI: https://doi.org/10.1038/nature02417

41. RYAN MG, PHILLIPS N, BOND BJ 2006 The hydraulic limitation hypothesis revisited. Plant Cell Environ 29 (3): 367-381. DOI: https://doi.org/10.1111/j.1365-3040.2005.01478.x 